\title{
Gender Ideology in The Story of Zahra
}

\author{
Rizqi Handayani \\ Translation Department, Faculty of Adab and Humanities \\ Syarif Hidayatullah State Islamic University Jakarta, \\ Indonesia \\ rizqi.handayani@uinjkt.ac.id
}

\begin{abstract}
This research aims at viewing gender ideology through the work of a female author which in this case is represented by the novel The Story of Zahra. This novel was written by a Lebanese female author Hanan Asy-syaikh (1945). As for the research method used is analytical descriptive method by using the literature feminist critic approach which was developed by Showalter through his gynocritics, theory. This method is used to reveal the gender ideologies which are found in the text of the novel The Story of Zahra as primary data. The data collection was done by the researcher as key instruments by reading the primary data. The data was then identified, classified and analyzed critically. The result of the research shows that female authors tend to articulate women in novels as a subject of gender thus making them be able to express their experience surrounding their bodies in an articulated way. In expressing her opinions on gender ideologies in The Story of Zahra, Syaikh raised the issue of femininity, female bodies and virginity in the Lebanese society as discursive practices born from the patriarchal society.
\end{abstract}

Keywords - translated literature, gender ideology, gynocritics, patriarchal society.

\section{INTRODUCTION}

In literary works creation, an author holds a significant role and oftentimes considered as super creator due to the fact that literary works bring the author's philosophy, thoughts, and experiences. In this view, all the author's experiences and thoughts are deeply immersed with the text thus making readers be able to see the works created by the author as an invisible autobiography [1, pp. 32-37], [2, pp. 101-106]. Literary works are also the products from the psychiatric condition and the thoughts of the author which are in the state of unconscious and conscious [3, p. 96].

The creation process of literary work is also a process of imagination which involves the experience of the author as an individual and social being who interacts with the surrounding society. Thus every author has different experiences. Thus male and female authors will have different perspectives in revealing the reality of life they face. According to Maqdisy, there are striking differences between the writing of literary works written by male and female. In literal works written by females there are elements of imagination and ideas that cannot be found in the literary works of male, especially with regard to their body and sexuality [4, p. 80]. On the other hand, the writings of male authors tend to be unisexual.

Every author is certainly coped with different experiences. Thus, a male or female author has different perspectives of expressing reality. According to Maqdisy, there is an obvious distinction of literary style written by a male and female author. Female literary works tend to pose imaginative substances and ideas compared to those of male literary works [4]. As the result, a female literature frequently brings a broader view of life and idea than those of the male literature.

It is therefore important to discuss female author as the subject of gender. Luce Irigaray sets a theory of this term as le parler femme (the speaking female). According to her, there happens to be female pre-symbol experiences. The premise is developed by jouissance or feminine sexual pleasure, play, and enjoyment that are beyond reasons. It then supports female author to write feminine literature through écriture feminine (female literature) and le parler femme (the speaking female) [5].

The above opinion is introduced by $[6, \mathrm{p} .13]$ as gynocritics, i.e the creation of literature written by female author aims to construct feminin ideas in literature.

There begins to appear various perceptions and conceptions of female literature issues for readers. In the sense that literature as a product of culture plays a significant role in creating gender ideology.

\section{METHOD}

This research uses a qualitative method by using feminist literary critics approach. This feminist literary critics is used to reconstruct female idea in literary works. I use the source novel The Story of Zahra [7] by Hanan Ash-Shaikh, and its translation by Kunti Saptowirini as the primary sources. Since this research is a library research, the data or information used are mostly taken from books, articles, and internet. The data used in this research is gender discourse in a text comprising femininity discourse, female bodies dan virginitas. After the gender discourse was verified then classified based on related gender issue. The issue is then analysed and interpreted using gynocrytics perspectives as proposed by Showalter.

\section{Gender Ideology Appears in the Novel}

Femininity is closely related to 'feminine' or 'having female attributes. It is an arbitrary category used by the patriarchal system to identify female attitudes and performances [8, p. 153]. The patriarchal society classifies male and female into feminine and masculine since they were born. They socially construct the femininity to the female born and the masculinity to the male born. Girls are always be encouraged to choose bright colors for their clothes and hair accessories while boys are always encouraged to choose dark colors for everything they wear. 


\section{RESULTS AND DISCUSSION}

In The Story of Zahra, feminine attributes are usually given to Zahra. Since she was a little girl, Zahra is always treated like a doll. Her hair is bunched with ribbons and accessories in her body. Her mother counts everything for Zahra [7, p. 7]. In patriarchal concept, women are demanded to look attractive and perfect in front of the public. In fact, a daughter is encouraged to be able to dress up herself and to behave polite and friendly.

"my mother, as usual, forced me to wear blue pants and a green t-shirt. She put my hair in order, and once in a while dipped the comb in a glass of water." [7, p. 4].

For her appearance, a daughter will usually imitate her mother or an adult woman as a perfect role model. Mother is the one who has the closest relationship with her daughter. When her mother dressed her up like an adult, she never complains about it. Instead, she considers herself copying her mother's character $[8$, p. 95]. She even imagines someday she will be a mature woman like her mother, getting dressed like her mother, a woman who holds sovereignty of power over her matriarchy. According to Chodorov, the construction of femininity gender identity has a correlation with psychological and cultural experience since she was destined as a feminine figure.

Social classification keeps growing from teenagers till maturities. Sons and daughters will have different ways of playing games and toys. A daughter is always encouraged to have dolls or domestic tasks.

"...the man who kissed me and hugged me also gave little dolls for me."[7, p. 10]

"always the same rubber doll...." [7, p. 18]

Furthermore, a daughter's personal education is more limited than a son. A daughter has to avoid hard tasks, such as physical violence. She hals to look charmed and pretty. A woman character is supposed to take around nursery tasks and domestic activities due to her physical weakness [9, p. 23]. Parents do not only engraft such principles, but also stick the living myths that can restrict freedom of expression for their daughters.

The classification of a man and woman as feminine and masculine will create different impact to educational and professional aspects. A young female will be controlled over developing her own career, but a young male will have more opportunities to get higher education for his future. The separation of role between a male and female will adverse consequences of female lost on domestic sphere. Hence, a woman is assumed as a powerless person to develop her future. On the contrary, a man has more freedom in develop his future in public sphere [8, p. 523].

Physical differences between man and woman can determine their position and status. A male is usually stamped to a technical field for he is considered as more rational, macho, masculine, and intellectual. On the other hand, a female is usually considered as a weak figure that is suited to have domestic activities, such as a nurse, secretary, teacher, accountant, and clerk.

\section{"My father's dream is all about how to earn money so that we can send Ahmad to study the electrical technique in America...however, Ahmad is hardly illiterate. In fact, he often gets rid of school... and my father is persistently planning to send him to America. Ahmad is used to having nice food from my father. Salubrious egg for Ahmad. Fresh tomato for Ahmad. On top of it, the biggest olive fruit is only for Ahmad" [7, p. 35].}

Her father, Ibrahim, as the main family feeder has the plan to send his only son, Ahmad, to study the electrical technique in America. Therefore he works hard to earn money in order to make his dream come true. Nonetheless, he never wishes to send his daughter, Zahra, to study in higher school. It indicates that Ibrahim discriminates her daughter into marginal position and drive his daughter into the corner of domestic function. A son is demanded to achieve his dreams and to develop his personal competence as high as possible. While a daughter tends to be unequally treated.

As a matter of fact, Zahra is a diligent student. Due to her excellent personal competence, she should have been treated equally as her brother, Ahmad, who is hardly illiterate. Stereotype attributed in women body, however, seems to be the reason for women marginalization in the domestic area. Women marginalization and discrimination can lessen human potential. According to Middlebrook quoted by Zahrotun Nihayah, among of the factors in declining self-esteem are education, different treatment of gender, and physical appearance [6, p. 13]. In the novel, Zahra's incapability can only be discovered through her internal communication.

\section{Female Bodies}

A woman is inextricably linked with her own physicalmyths. Let alone if the standardizations of the female body are constructed by a patriarchal system. A female body concept convinces that a woman who has an attractive and beautiful body will find her spouse immediately. As a mature woman, she will have bargaining position if she looks attractive and beautiful.

In The Story of Zahra, people in Lebanon believe that a perfect woman is defined by her physical appearance. She should look clean, soft, and have bright skin-face, like Chinese porcelain. "Take care of yourself, Majid, take care, my dear. Keep your distance from the African girls; they are an epidemic. They know how to trap the white man like you, and as soon as you become surrender, they had themselves pregnant. They are stuck on you like a leech and reject abortion. Soon after the baby was born, she will be yours, willy-nilly. If it is true, that's not the problem, but five minutes before you come, those women might have just slept with another man" [7, pp. 120-121]

People in Lebanon would keep their distance from African women due to their black skin. They believe that a dark-skinwoman will bring disaster and epidemic. A black skin woman 
is considered as an epidemic for she can give birth to the lineage of big-thick-lips, barbarian hair, and black skin descendants. Having a black skin child makes white skins discomfort since black skin child will be insulted by the other white skin children of the same age. It happens to Majid's neighbor, Derwish's daughter, Maha, in Beirut. Maha is the daughter of African black woman. She is always mocked by white skin children, "the black girl...the black-skin-girl and her white-teeth." She is supposed to have a problem in her future for there is nobody will marry her.

"who wants to marry her, with the tousled hair and

burned skin? Poor girl! Do you want to have a child who is always mocked that way, and so does you? [7, p. 121].

The perfection of woman body is measured through her spotless skin. The skin flaw can make a woman feel discomfort, particularly those who are in the age of puberty. Zahra considers blotches on her face as a physical defect and imperfect. Her parents always fault finding her to consume inhibited food and drink that can threaten her beauty and healthy, such as candy, pickles, and chili, to name a few.

“the spots. They're gonna go soon. Or they will say, "that's the reward for the candy you have." Or others would say, "it's because of your pickles, and hot chili" [7, p. 35].

Ibrahim feels anxious to find blotches on Zahra's face for there will be no one to marry her. He will be angry if he finds Zahra scratches off pimples on her face.

"he will be very angry with me if he finds me scratching off pimples on my face" [7, p. 34].

"my father will be furious everytime he finds problems on my face. He will blow up my mother scornfully: "There will be a time for Zahra to marry. What a lovely day for her and her blotch face!" once he hit me while I was scratching off pimples in front of mirror" [7, p. 35].

The unpleasant demeanor of her parents sets aside longlasting nasty experience for Zahra. She wants to get rid of such uncomfortable feeling from her soul. However, she finds her pimples on her face as a big problem that can block her way to have a relationship with anyone. Once she deliberately decided to make a relationship with a man, Malik, even though she knew he had wife and children. Indeed, Malik never complains about the pimples on her face. He even feels more impassioned to treat her like an oyster.

"Anyone whose face and body resemble with me can be persuaded easily, but that's the way how to make it more reasonable for me. He ever once told me that he liked pimples on my face. He even felt more impassioned to lie-down on my body and wanted to treat me like an oyster" [7, p. 43].

It indicates that women sexuality is always considered through her physical appearance as the object of men sexual satisfaction. Definitely, we need to be fair in the case of women physical

appearance that those who live in "cultural inadequacy" of adorable beauty community will always be impressed by falsify contentment. From the bottom of her heart, Zahra realizes for the unattractive condition of her pimply face and physical deficiency. After all, she considers it as a reasonable action.

\section{Virginity}

The word 'virgin' was absorbed into English in approximately 1200 s, particularly to name"Marry the virgin" in the early Christianity time. This story told about a devout, and holy virgin who firmly adhered to her religion, notably in Christianity church. Later on, women virginity began to be the symbol of women dignity and chastity. Kate Millet argued virginity concept as chastity standardization, for virginity is still contra productive in a patriarchal system. On the one hand, virginity is considered mysterious and sacred. On the other hand, virginity is considered to bring evil and calamity for it is frequently linked with women genital blood [10].

Virginity is not part of the woman body, but it is rather a social construction for the good woman standardization. A woman is considered as a good woman if she can protect her virginity for her husband. Virginity concept is very valuable for an unmarried woman. So that there will be a serious calamity for a girl who lost her virginity before she gets married. Furthermore, oriental society considers it taboo for a man or woman who commits adultery before getting married. Therefore, they will always be haunted by the sense of sinful and wrong-doing for all their life, family, religion, and society [9, p. 157].

\section{"...the day will come to me and my husband will find me not virgin anymore. It's time for my husband to know that I had carried twice-abortions." [7, p. 41]. "...I felt as the other girls I knew, the girls who've been living with their preventive-tenet-parents. The shadow of my father, however, has frequently appeared in my mind that made me fearful for my father would have killed me if he knew what had happened to me" [7, p. 43].}

Hymen in this context has double functions, i.e as a symbol of virginity and to define body boundaries of a woman. Apart from the cultural function of virginity, Lama Abu Odeh explains that a man does not have the cultural function of virginity, but a man "virility" is defined by his struggle to making a pitch for woman virginity in his family. Patriarchal system believes that a man reputation heavily relies upon woman sexuality. Take for the fact, an honor is not only about virginity protection, but it is also about a man who can secure everything from ruining his male status.

It also happens to the concept of virginity that is always used to differentiate between good and bad woman. People in Lebanon believe that their family dignity is determined by their daughters' dripping virginity blood of the first wedding night. Patriarchal culture is the unwritten social fervent dogma 
living in society. In this case, women seem to support the patriarchal system without reconstruction.

\section{CONCLUSION}

Based on the novel The Story of Zahra, the research shows that female authors tend to articulate women's experience on body and sexuality as a subject of gender. Besides that, female authors can express the experiences of women very articulately. This is evident from the efforts of the female author to explain the gender function which is inherent in the body of women as consequences of discursive practices that are born from the patriarchal society around them. However, one thing that is unfortunate is that the idea on women's' body and sexuality which are independent in literary works are constantly confronted with the reality and patriarchal interests, so at times the female character in literary is able to become the subject by determining her own fate and choices. But at other times women do not have any choices which make them very dependent on the patriarchal social construction.

\section{REFERENCES}

[1] Atmazaki, Ilmu Sastra: Teori dan Terapan. Padang: Angkasa Raya, 1990 .

[2] J. Hillis Miller, On Literature: Aspek Kajian Sastra. Yogyakarta: Jalasutra, 2011.

[3] Suwardi Endraswara, Metodologi Penelitian Sastra. Yogyakarta: Pustaka Widyatama, 2004.

[4] Zhabiah, Khamîs, Shunmu al-Mar'ah al-Syi'riy. Beirut: Dâr li atsTsaqâfati wa al-Nasyri, 1997.

[5] C. Barker, Cultural Studies: Teori dan Praktek. Yogyakarta: Kreasi Wacana, 2000

[6] Z. Nihayah, Psikologi dan Perempuan dalam Potret Perempuan dalam Teori dan Realitas: Meretas Paradigma Kesetaraan. Jakarta: Pusat Studi Wanita, 2007.

[7] H. asy-Syaikh, The Story of Zahra. Jakarta: Pustaka Alvabet, 2006.

[8] M. Humm, "Ensiklopedia Feminisme.” Fajar Pustaka Baru, Yogyakarta, 2002.

[9] S. de Beauvoir, Second Sex. Ttp: Pustaka Promethea, 2003.

[10] M. Amiruddin, "Kata dan Makna,"J. Peremp. Seksualitas, p. 111. 